Lexis Vol. XLIV (1) 2020: 317-341

\title{
Una aproximación comparada a la ciudad-sueño: Mario Levrero y Mircea Cărtărescu*
}

\author{
Alba Diz Villanueva \\ Departamento de Estudios Románicos, Franceses, Italianos y Traducción \\ Universidad Complutense de Madrid
}

\section{RESUMEN}

La narrativa de Mario Levrero y la de Mircea Cărtărescu, aunque de estilos y temáticas bien diferentes, conceden un papel preponderante a los sueños $\mathrm{y}$ al onirismo. Son justamente las consecuencias que ello tiene sobre la configuración del espacio, en tanto que dan lugar a un modelo cultural urbano (la ciudad-sueño), el objeto de este estudio. En concreto, el presente trabajo analiza las características de dicho modelo en la Trilogía involuntaria de Mario Levrero y la trilogía Orbitor de Mircea Cărtărescu, focalizando en las concomitancias y particularidades que presentan los textos de uno y otro autor.

Palabras clave: espacio urbano, onirismo, ciudad-sueño, Trilogía involuntaria, Orbitor

\footnotetext{
"Este trabajo se inscribe en el marco del proyecto I+D FFI 2016-77157-P Nuevos modelos urbanos en la postmodernidad. La no-ciudad y sus representaciones literarias y artísticas, financiado por el Ministerio de Economía, Industria y Competitividad.
}

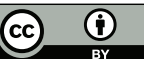

https://doi.org/10.18800/lexis.202001.011 
A Comparative Approach to the Dream-city: Mario Levrero and Mircea Cărtărescu

\begin{abstract}
Despite the stylistic and thematic differences between them, Mario Levrero and Mircea Cărtărescu give a main role to dreams and onirism in their narrative texts. This fact has consequences for the fictional space inasmuch as it results in an urban cultural model (dream-city). This paper analyses Levrero's Trilogía involuntaria and Mircea Cărtărescu's Orbitor in order to examine the specific characteristics of that model, the main differences and concomitances.
\end{abstract}

Keywords: urban space, onirism, dream-city, Trilogía involuntaria, Orbitor

Jorge Mario Varlotta Levrero, más conocido como Mario Levrero (Montevideo, 1940-2004), es un escritor uruguayo polifacético, autor de una obra extensa y variada, que comprende desde novelas de ficción —como La ciudad (1970), París (1980) y El lugar (1982), que conforman la Trilogía involuntaria en la que se centra este trabajo-, de autoficción o parodias del género policíaco a volúmenes de cuentos, artículos periodísticos, folletines experimentales e, incluso, guiones de cómics. Levrero ha recibido una consideración irregular por parte de la crítica: aunque en los inicios de su trayectoria el escritor, catalogado por Rama como uno de los “raros” de la literatura uruguaya junto a Felisberto Hernández ${ }^{1}$ o José Pedro Díaz, no alcanzó apenas reconocimiento ni atención crítica, debido ello quizá al cultivo de formas tradicionalmente consideradas "menores”, “populares” (como el folletín o el guion de cómic) o incluso "marginales, si se comparan las mismas con el canon realista imperante” (Olivera 2008: 165), en los últimos años sus obras,

\footnotetext{
1 Montoya Juárez (2013: 64) sitúa al autor en la línea felisbertiana por su literatura imaginativa, desenganchada "de un corpus hegemónico que había pretendido estructurar una imagen inmediata de la realidad según los parámetros convencionales de la representación realista”.
} 
especialmente las de la etapa final de su proyección, han suscitado un interés creciente entre los estudiosos. ${ }^{2}$

Mircea Cărtărescu (Bucarest, 1956) es, en cambio, una de las figuras más importantes del panorama literario rumano actual. Desde su debut, en la década de 1980, hasta el presente, cuando es ya un autor consagrado dentro de las fronteras de Rumanía - y, cada vez más, también fuera de ellas ${ }^{3}$ - ha recibido una atención especial por parte de la crítica. Dentro de su obra, extensa tanto en número de publicaciones como en géneros comprendidos (poesía, cuento, novela, ensayo, teoría literaria, diario, artículos de opinión, literatura para niños), la trilogía Orbitor es el proyecto literario más importante publicado hasta la fecha, que condensa, como él mismo ha expresado, todos sus escritos anteriores (Chițan 2007). Como dejan ver los subtítulos de cada uno de los tres tomos - Aripa stângă ("El ala izquierda”) (1996), Corpul (“El cuerpo") (2002) y Aripa dreaptă ("El ala derecha”) (2007)—, la trilogía se configura en forma de mariposa, un símbolo polivalente de gran relevancia en este y otros textos del autor.

Aunque de estilos bien diferentes, la narrativa de Levrero y la de Cărtărescu comparten, entre otros rasgos, una fuerte presencia del onirismo, sobre todo en lo que atañe a la configuración del espacio, de naturaleza eminentemente urbana. En la reescritura de la ciudad que realizan estos dos autores es posible reconocer, como se tratará de demostrar, un mismo modelo cultural urbano: la ciudad-sueño. Este término hace referencia a aquella representación de la ciudad que, pese a pertenecer al plano de la vigilia, se aleja de la urbe literaria real (así percibida dentro del universo de la ficción por los

\footnotetext{
2 Ver, entre otros, De Rosso (2013), Eguía Armenteros (2017), Martínez (2017), Martínez Sánchez (2016), Oliver (2013), Pérez Armendáriz (2017), Vecchio (dir.) (2016).

3 Prueba de ello son las traducciones de sus obras a distintas lenguas (español, catalán, inglés, alemán, italiano, euskera, francés, búlgaro, sueco, portugués, etc.) y los premios internacionales recibidos: "Haus Der Kulturen der Welt” (Alemania, 2012), "SpycherLiteraturpreis Leuk” (Suiza, 2013), Festival Internacional de Poesía de Novi Sad (Serbia, 2013), "Österreichischer Staatspreis für Europäische Literatur" (Austria, 2015), Formentor (Argentina, 2018) o Thomas Mann de Literatura (Alemania, 2018), por citar solo algunos.
} 
personajes) con la que convive y presenta características similares a los espacios del sueño: incoherencias espacio-temporales, conexiones entre lugares geográficamente distantes, escenarios sobrenaturales, arquitecturas imposibles desde el punto de vista de la lógica, lugares que cobijan criaturas o hechos extraordinarios. Todas estas características transgreden las leyes racionales que actúan en la realidad y en aquellas representaciones literarias más próximas a ella. En consecuencia, la ciudad-sueño se diferencia de la ciudad soñada, esto es, la ciudad con referente real (en el marco ficcional) o imaginaria que durante el proceso del sueño crea la mente del sujeto que duerme y que no existe como tal fuera de ella.

Mario Levrero manifestó en repetidas ocasiones, tanto a través de sus escritos como en entrevistas, su interés por fenómenos parapsicológicos, ${ }^{4}$ por lo onírico y por todas las manifestaciones del inconsciente (Echevarría 2008). Para él, los sueños no dejan de ser experiencias de la realidad, una realidad cuya esencia es difusa e imprecisa, y escapa a categorizaciones y conceptos. Al carecer de un lenguaje propio, esos movimientos interiores que trató de expresar en su obra - y de manera especial en la Trilogía involuntaria- se vehiculan a través de una escritura simbólica, plagada de imágenes, como manifestó el propio autor (Pereira 2013: 70).

El onirismo es también un rasgo destacado de la narrativa de Mircea Cărtărescu, que ha hecho notar la crítica que se ha acercado a ella (Pop 2010; Bârleanu 2011; Axinte 2007; Centrul de Cercetare al Imaginarului 2005; Ungureanu 2007). Los sueños y otros estados afines - la ensoñación, la alucinación, el delirio febril, paranoico o esquizoide- se encuentran con mucha frecuencia en sus novelas y cuentos, hasta el punto de vertebrar la narración, como sucede en su relato "REM" o en la última novela publicada por el autor hasta la fecha, Solenoid, donde una parte significativa de la materia narrativa está constituida por sueños o fragmentos de sueños pasados

\footnotetext{
Bello Rodríguez lo define en términos de parapsicólogo y telépata, de defensor de la hipnosis como procedimiento terapéutico y de las percepciones extrasensoriales (Bello Rodríguez 2014: 84-85).
} 
que el narrador-protagonista ha rescatado de su diario personal. En este sentido, tomando como base justamente el componente onírico, este diario cabe ser interpretado como un trasunto ficcional del diario de Mircea Cărtărescu, que él mismo ha definido como un libro de sueños (Teodorescu 2007). Los cuatro tomos publicados del diario constituyen, según apuntan algunos estudiosos y el propio escritor (Ciobanu 2002; Tuca y Suciu 2005; Teodorescu 2007), un plan de trabajo, un esbozo de taller literario o cuaderno de escritura en el que los episodios oníricos, sean o no ficticios, tienen una presencia importante junto a las ideas, los temas, los personajes, etc. que constituirán las bases de textos posteriores. Su relevancia en el universo narrativo cartaresquiano se constata con solo aproximarse a los textos, pero viene anticipada ya en sus diarios, por el hecho de ser incluidos los sueños entre los elementos germinales o centrales de sus principales novelas y relatos, y de manera notoria en Orbitor.

Los episodios oníricos proporcionan a Levrero y a Cărtărescu imágenes que después incorporan a sus obras como materia literaria. Sin embargo, el presente estudio tiene por objeto el sueño, desde el punto de vista no tanto de su recurrencia en el imaginario de estos autores, cuanto de su función a la hora de configurar el espacio narrativo, en su condición de elemento generador del modelo urbano presentado. No obstante, es precisamente en las descripciones de los sueños - a menudo minuciosas - donde se observa que las principales características del universo onírico persisten en el modelo urbano de la ciudad-sueño.

Como consecuencia de lo anterior, la ciudad-sueño está muy relacionada con el universo onírico, con el que mantiene una relación bidireccional —ambos se nutren mutuamente-, pero lo está también con el sujeto que la habita, cuyos recuerdos, anhelos, frustraciones o fobias se ven a menudo proyectados sobre el espacio urbano, contribuyendo a acentuar, cuando no a generar, el onirismo. En la narrativa de ambos autores, mundo onírico y mundo interior son una "parte de la realidad, trenzada imperceptiblemente con las demás" (Coşovei 2009); por tanto, las fronteras entre sueño y vigilia, realidad y alucinación, memoria e imaginación, interior y exterior 
se difuminan. En el caso de Levrero, esta indistinción entre realidad y sueño -especialmente presente en la Trilogía involuntaria pero también en la escritura autoficcional, como en el Diario de la becatiene su manifestación más clara y más concreta en un episodio de París, en que el protagonista vive de forma simultánea dos realidades distintas, paralelas: la del sueño y la de la vigilia, que acaban por converger en el mismo plano. Así, el yo se desdobla, se fragmenta: vive en la vigilia y, al mismo tiempo, se contempla en el sueño, hasta que finalmente los dos yoes escindidos confluyen en las calles parisinas:

Se me ocurre que puedo terminar con esta dualidad que ya me incomoda demasiado, buscando una coincidencia con el yo del sueño [...]. [...] pienso que puedo intentar comunicarme con él y atraerlo $[\ldots]$.

[...] Ahora, al acercarme, puedo verlo de frente: es alguien exactamente igual a mí. Debo acercarme siempre lentamente, porque cuanto más me acerco más sé de él, como si fuera absorbiendo toda su memoria, incorporando todo su pasado. Por fin logro ser él mismo, $[\ldots]$ y saber que, para él, yo había sido simplemente el actor de sus sueños. Ahora somos una sola persona [...].

[...] Me pregunto si este yo consciente que ahora se encuentra aquí en la esquina es el del sueño o el de la vigilia; y es una pregunta que no puedo contestar. Lo único cierto es que ahora vivo una sola acción, única (Levrero [1980] 2010: 99-100).

La conexión entre la realidad interior y la realidad exterior se plantea necesariamente en términos de continuidad. El lugar insiste en este continuum, a través de las palabras de su protagonista: "me obsesiona la idea de estar demasiado ligado al mundo exterior; de que, en realidad, todo mi ser forma parte del mundo exterior; no puedo precisar los límites: hasta aquí el mundo exterior, aquí empiezo yo [...]. A veces pienso si no somos otra cosa que cortes de situaciones exteriores..." (Levrero [1982] 2010: 23-24). De hecho, en esta novela se llega a plantear que uno de los espacios, donde se concitan varios personajes sin saber cómo han llegado a él, podría ser resultado de la combinación de los sueños de todos ellos. Por ende, 
los sueños, en tanto que parte de la vida interior, están estrechamente ligados a la vida exterior y, en casos como el anterior, llegan a tomar concreción física, a materializarse en el plano espacial.

El clima onírico y la fuerte carga subjetiva de los espacios de la Trilogía involuntaria ponen en tela de juicio la experiencia objetiva: el espacio, como el tiempo, es un signo de vivencias personales, intransferibles y únicas (Corbellini 1996: 21). Así, los sentimientos de frustración que sobrevienen constantemente en el entorno urbano a los protagonistas de cada una de las novelas de la trilogía proceden muchas veces no tanto de la ciudad como de ellos mismos, que exteriorizan y proyectan sobre el espacio sus propios conflictos.

Esta misma porosidad entre los límites de la realidad, el recuerdo, la imaginación, el sueño o la alucinación se plantea en los textos cartaresquianos, donde se encuentran fenómenos similares a los vistos en Levrero. Los sueños y ensoñaciones de los personajes, intensos y vívidos, se retroalimentan: espacios de la realidad aparecen en los sueños, al tiempo que los oníricos se superponen a los reales. Este fenómeno es definido por Mircea, el protagonista de Orbitor, como un continuum realidad-alucinación-sueño (Cărtărescu [1996] 2014: 41), que es un rasgo definitorio de la narrativa del autor.

Paralelamente, la veracidad de los recuerdos es también cuestionada con frecuencia, debido a su relación con la esfera onírica. El protagonista de París, por ejemplo, si bien a su llegada a la ciudad parece hallar una correspondencia entre el paisaje urbano y sus recuerdos, poco después pone en duda su memoria y aun sus supuestas experiencias pasadas en la ciudad. También en Orbitor es habitual la interrogación acerca del origen de los recuerdos, materia inextricable en la que a las experiencias efectivas se suman las oníricas y las alucinatorias:

Unde să te uiți şi-n cine să crezi, când în vise-ți aminteşti alte vise şi-n acele vise-ți aminteşti lucruri niciodată-ntâmplate, iar alte privelişti care-ți apar brusc în minte pe când mănânci sau citeşti neatent o carte le iei drept bizare capricii ale vreunui demon interior, când sunt de fapt engrame fidele ale unor fapte petrecute pe când vedeai cu nişte ochi mai mari şi gândeai cu un creier mai mic şi mai rudimentar? 
[...] e cu neputință să discerni atunci unde, pe harta ca o plasă de păianjen, tridimensională şi nesfârşită, a situației tale în lume, te găseşti cu spaima şi fascinaţia ta: în fundătura Iluziei, în şoseaua Reveriei, în parcul Memoriei, în gara Halucinației, în cartierul Realității... Mai curând îți poți imagina c-ai înțepat c-un ac harta pliată, unind zone incompatibile şi-ndepărtate într-un traiect de neînțeles, perpendicular pe foaie, ocult, străpungând existența dinspre nimic spre nimic, aşa cum noi înşine unim, cu traseul paradoxal al vieților noastre, incongruențe patetice: naşterea şi dragostea, arta şi nebunia, fericirea şi moartea... (Cărtărescu [1996] 2014: 399-400). ${ }^{5}$

En la ciudad-sueño las leyes lógicas se anulan. En primer lugar, no siempre existe causalidad entre los hechos que tienen lugar en ella, que son a menudo azarosos y se suceden sin ninguna conexión, especialmente en el caso de la trilogía levreriana. En segundo lugar, la concepción del tiempo o, mejor dicho, la temporalidad no se corresponde con la imperante en la ciudad-real: en las novelas consideradas, de uno y otro autor, se narran viajes, descensos, ascensiones...de siglos de duración, que en Orbitor se corresponden con apenas unas horas en la "realidad” intraliteraria. Además, la cronología histórica es vulnerada: si en la primera de las novelas de Cărtărescu se recrea el gran bombardeo de las fuerzas aéreas anglo-americanas de abril de 1944 y se sitúa un año antes, en 1943, en el París levreriano, por su parte, conviven Carlos Gardel, Charles de Gaulle y Hitler, como se verá más adelante. En cuarto lugar, se establecen conexiones entre

\footnotetext{
5 “¿Adónde mirar y en quién creer, cuando en sueños te acuerdas de otros sueños, y en esos sueños recuerdas cosas jamás ocurridas y otros paisajes que se te aparecen bruscamente mientras comes o lees distraídamente un libro y los tomas por extraños caprichos de algún demonio interior, cuando son en realidad fieles engramas de hechos que tuvieron lugar cuando veías con unos ojos más grandes y pensabas con un cerebro más pequeño y más rudimentario? [...] te resulta entonces imposible desentrañar, en el mapa como una tela de araña, tridimensional e infinita, de tu situación en el mundo, dónde te encuentras [...]: en el callejón sin salida de la Ilusión, en la carretera de la Ensoñación, en el parque de la Memoria, en la estación de la Alucinación, en el barrio de la Realidad... Más bien puedes imaginarte que has pinchado con una aguja el mapa doblado y has unido zonas incompatibles y lejanas en un trayecto incomprensible, perpendicular a la hoja, oculto [...]". [Nota de los editores. Todas las traducciones del rumano pertenecen a la autora del artículo.]
} 
zonas geográficas distantes. Por ejemplo, en Orbitor, a través de una casa concreta del callejero bucarestino llegan varios personajes a Amsterdam, mientras que los accesos a un mismo espacio subterráneo se suceden en distintos puntos de la capital rumana y del orbe, como en Bellagio o New Orleans. En quinto lugar, algunos personajes presentan, en el marco de la ciudad-sueño, características y habilidades de las que comúnmente carecen. Es significativa, a este respecto, la coincidente habilidad de los protagonistas de la trilogía cartaresquiana y de la novela París de Levrero: mientras que Mircea emprende, en no pocas ocasiones, vuelos y ascensiones que le permiten obtener visiones inusuales de la urbe, el protagonista levreriano descubrirá unas alas en su espalda, en virtud de las cuales sobrevolará, como otros seres de su misma condición, la capital gala.

La continua metamorfosis espacial es uno de los rasgos principales del modelo urbano analizado. Hay pues en la ciudad-sueño, como en la ciudad soñada, escenarios cambiantes, que mutan su textura, su apariencia, su temperatura. En algunos espacios laberínticos por los que se pierde el protagonista de La ciudad, las paredes húmedas y resbalosas se ensanchan, pierden sus líneas rectas en favor de otras curvas y esféricas, dificultando sobremanera la orientación en su interior. En cambio, en París, son los colores los que cambian, debido quizá, como apunta el propio personaje, a una proyección de su afectividad sobre las cosas y los espacios que, en sí mismos, carecen de ellos:

Observo que sucede algo extraño con los colores de las cosas. La puerta, por ejemplo. El color de la puerta se mueve, se reduce y de pronto vuelve a crecer. Las paredes. Angeline se ha vuelto, dormida, hacia la ventana; y el rojo de sus labios es tembloroso, vacilante, como si quisiera desaparecer. Lo mismo que el color del camisón y el color de la carne. A menudo aparecían grandes sectores grises, y luego el color retomaba la superficie que ocupaba inicialmente. Lo mismo sucedía con todas las cosas, como si...

... como si fuera una película en blanco y negro - pensé-, que alguien hubiese pintado a mano toscamente, cuadrito por cuadrito (Levrero [1980] 2010: 123). 
Similares procesos, más pronunciados si cabe, afectan a los ya mencionados escenarios subterráneos de Orbitor, que pierden su naturaleza material en virtud de una orgánica. El suelo se torna elástico y pegajoso - lo cual dificulta el paso-y los demás elementos, desde las losas hasta los objetos decorativos, van perdiendo sus formas hasta reabsorberse en la pared, cuya textura es ahora húmeda y cálida, viscosa, elástica. Así, el mármol, el pórfido, el bronce, el ladrillo y demás materiales que los conforman se convierten en huesos, vísceras, membranas o tendones. Este fenómeno resulta de la hipérbole de una metáfora frecuente en los textos cartaresquianos: la de la ciudadcuerpo. En este modelo o metáfora urbana, la ciudad se presenta como un organismo humano, tanto desde el punto de vista anatómico - de manera que los elementos urbanos se corresponden con distintas partes del cuerpo, con las que se asemeja por su forma o función-, como desde el punto de vista psicológico, siendo la urbe susceptible de experimentar sentimientos y establecer vínculos emocionales.

En Orbitor, esto se plasma en el que, debido a su recurrencia narrativa y a su significado, es el principal escenario de la ciudadsueño. Se trata de una gran sala circular, subterránea, a la que acceden distintos personajes desde puntos diversos de la capital rumana (y desde otras urbes con las que esta conecta), en cuyo centro se ubica un féretro de cristal, que acoge, en distintos estadios de su desarrollo, a la mariposa que eclosionará al final del tercer volumen, cuando culmina su metamorfosis y, al mismo tiempo, la trilogía que simboliza. Este espacio, en sus distintas hipóstasis a lo largo de los tres tomos, se asimila a un útero-cerebro, ${ }^{6}$ mientras que los túneles que conducen a él se identifican con vaginas, venas, etc. De esta manera, esa caverna materializa uno de los valores simbólicos que por lo común se asocian a este espacio, el de matriz o vientre materno (Chevalier [1969] 1986; Evseev 1994; Cărtărescu [1992] 2011), que resulta ahora equiparado, por su potencial creador, al cerebro humano.

\footnotetext{
6 De acuerdo con la concepción corporal que se expone en esta obra, la simetría del cuerpo humano no es solo horizontal, sino también vertical. En este último plano, el eje viene dado por el diafragma.
} 
Un caso particular de transformación es el que experimentan las estatuas de la ciudad, un pueblo vivo "condenado a la parálisis eterna" (Cărtărescu 2007: 391), que, en las ensoñaciones del protagonista, cobra vida y abandona sus ubicaciones habituales en las plazas y los edificios bucarestinos, ya sea para liderar la Revolución de diciembre de 1989 — hecho que se retomará más adelante-, ya sea para satisfacer en multitudinarias orgías sus necesidades sexuales, durante largo tiempo reprimidas:

Statuile orașului, deznădăjduiții, muțiii, neconsolații săi locuitori, de la bărbații de stat de prin piețe, acoperiți de găinaț de porumbel, până la embrionii monstruoși din ouăle de piatră, așteptau, infinit răbdătoare, nopțile în care zborul lui Mircea le-nsuflețea pentru un sfert de ceas. Atunci [...] coborau, de pe fațade și socluri, bărbați și femei în falduri de piatră, de aramă sau de ipsos lepros, se-mbrățișau cu priviri tragice când, grupuri-grupuri, se-ntâlneau pe străzile tăcute şi pustii, pentru ca apoi, în bezna parcurilor, să dedea unui desfrâu fără limite, unei obscenități disperate, avide de viață și sex, unei risipite de spermă minerală ce, țâşnită pe iarbă și pe frunzele boscheților, cristaliza în bobițe limpezi, ca de rășină de prun, pe care copiii le găseau diminețile următoare [...] (Cărtărescu 2007: 66-67). ${ }^{7}$

Otra característica común a la ciudad-sueño de ambos autores es la hostilidad que revisten los escenarios, que procede muchas veces de su propia configuración externa, de su estructura arquitectónica. En el caso del escritor rumano, su carácter misterioso, sus estremecedoras (o incluso infinitas) dimensiones y su arquitectura monumental (pilastras y columnas, escaleras, cúpulas... de gran

\footnotetext{
7 "Las estatuas de la ciudad, sus desesperanzados, mudos, desconsolados habitantes, desde los hombres de Estado de las plazas, cubiertos de excrementos de paloma, hasta los embriones monstruosos de los huevos de piedra, esperaban, infinitamente pacientes, las noches en que el vuelo de Mircea les daba vida durante un cuarto de hora. Entonces [...] bajaban, desde las fachadas y los zócalos, hombres y mujeres en faldas de piedra, de cobre o de yeso leproso, se abrazaban con miradas trágicas cuando, grupo tras grupo, se encontraban en las calles silenciosas y desiertas, porque después, en la oscuridad de los parques, se entregarían a un desenfreno sin límite, a una obscenidad desesperada, ávida de vida y de sexo, a un derroche de esperma mineral que, derramado sobre la hierba y las hojas de los bosques, cristalizaba en gotitas claras, como de resina de ciruelo, que los niños encontraban a la mañana siguiente $[\ldots]$ ”.
} 
envergadura y de materiales nobles), las extrañas criaturas que los habitan, así como las constantes aperturas del espacio, hacia arriba y hacia abajo, en el eje vertical dominante en este modelo ${ }^{8}$, atemorizan a los personajes que acceden a ellos. A este respecto, cabe mencionar dos episodios, simultáneos aunque no coincidentes en el plano temporal de la ciudad real (en el sentido ya señalado de este término), que tienen lugar en Orbitor. Se trata de dos descensos, desde dos enclaves distintos de la capital rumana, a los subterráneos que permanecen privados a la vista de la mayoría de la población, protagonizados por dos personajes: Maria, la madre de Mircea, por un lado; y, por el otro, Ionel, un amigo de esta y de su marido. Aunque los conductos que los llevan hasta allí son muy diferentes, pues en el caso del segundo carece por completo de la monumentalidad de la cripta en el cementerio Bellu en la que se interna Maria, en los dos casos, tras un trayecto que ambos perciben como interminable, el espacio en que derivan los sobrecoge. Ello se debe a sus “dimensiones inhumanas” (Cărtărescu [1996] 2014: 194) —la cúpula que lo recubre es comparada por su tamaño con la celeste-, a la luz de inexplicable procedencia que lo ilumina, así como al carácter amenazante de sus elementos, desde las gigantescas esculturas que representan a hombres y mujeres con malformaciones, enfermedades y demás calamidades humanas, hasta las mutaciones experimentadas por algunos de sus componentes, que intensifican, en conjunto, la sensación de irrealidad.

En la trilogía del escritor uruguayo, la disposición de algunos espacios genera desconcierto en los personajes. La estructura de la estación de nafta de La ciudad, por ejemplo, es cuanto menos contradictoria, puesto que su apariencia externa no se corresponde con su interior: si desde fuera parece una construcción baja, de una única planta, y aislada del resto, una vez dentro descubre el protagonista una segunda altura, muy amplia, así como pasillos que conectan con

\footnotetext{
8 En la ciudad-sueño de la trilogía, predomina, frente al eje horizontal dominante en la ciudad real, el eje vertical. Los personajes descubren entradas, escondidas en los lugares más remotos de Bucarest, a grutas subterráneas, al tiempo que experimentan vuelos y ascensiones hacia el extremo superior de este eje, alcanzando incluso el espacio exterior.
} 
otros edificios. Esta absoluta falta de lógica espacial se extiende más allá de este edificio, llegando a comprender una extensión significativa del extraño lugar, para mayor frustración del extranjero que arriba por vez primera a esta ciudad:

Sin darme cuenta, me encontré dando vueltas a la manzana ocupada por la estación de nafta. Esta manzana no tenía forma de cuadrado, y me pareció que no se ajustaba a ninguna figura geométrica simple. Los mismos elementos que componían la parte que yo mejor conocía, frente al bar, se repetían muchas veces, pero dispuestos siempre en distinta forma, y variando su cantidad. (Encontré los surtidores, la oficina, los carteles de propaganda y de bienvenida, las luces de colores, los grandes focos - todo repetido, formando distintas combinaciones a lo largo del contorno) (Levrero [1970] 2010: 107).

La sensación de extrañeza aumenta cuando encuentra unos mapas, cuya configuración territorial (de la ciudad, de la República, del continente y aun de la tierra entera) difiere por completo de sus conocimientos geográficos y de su experiencia directa, esto es, de lo que observa in situ. El protagonista da también con unos libros en un idioma ininteligible que no logra reconocer, y que es el empleado, al parecer, por la misteriosa empresa que posee el pueblo y que impone un estricto reglamento que le resulta absurdo, totalmente carente de sentido. El espacio urbano es un entorno generalmente incomprensible para los personajes levrerianos, que se muestran superados por las normas que lo rigen, o bien por la ausencia absoluta de las mismas y, en general, de toda coherencia. Ni el protagonista de La ciudad ni el de El Lugar cuentan con códigos lógicos ni lingüísticos compartidos con otros individuos que permitan la comunicación, lo que agrava la situación de aislamiento y los sentimientos de desconcierto y de angustia. De igual modo, el hecho de que los personajes lleguen a tales espacios fortuita, inexplicable o incluso disparatadamente contribuye en gran medida a su desorientación casi constante en el entorno urbano.

La hostilidad, que se manifiesta en distintos grados, puede ser más o menos directa. Además de la violencia física, en algunos casos 
indiscriminada, que se produce en ellos, se puede reconocer una violencia indirecta, psicológica, provocada por la ausencia de armas o claves para enfrentarse a unos espacios laberínticos o misteriosos. Por ejemplo, el París al que regresa el protagonista de la novela homónima es una ciudad caótica, deshumanizada y alienante, donde la muerte de sus habitantes se asume con total normalidad e incluso indiferencia y donde las formas de violencia más depravadas y crueles están normalizadas y son difundidas por los medios de comunicación. Esto convive, además, con importantes convulsiones sociales, que acrecientan la peligrosidad de los espacios públicos, especialmente de las calles parisinas. El protagonista deriva en un asilo, que es a la vez prostíbulo y cárcel, donde será privado de su libertad y sometido a castigos físicos. Ello, sumado a las turbaciones que la desorientación y la incomprensión de tal entorno le provocan, hace de los espacios privados parisinos entornos tan sofocantes y opresivos como los públicos.

Asimismo, en El lugar, el laberinto aparentemente interminable de habitaciones donde despierta el protagonista sin poder recordar cómo ha llegado o cómo lo han llevado hasta allí lo oprime tanto o más que aquella otra ciudad, su ciudad, que logra alcanzar por fin al final del relato. Mientras que en el primer espacio, formado por una sucesión de habitaciones por la que se puede avanzar pero no retroceder, la huida parece imposible, en el segundo la integridad física de los habitantes está amenazada por poderes represivos, por organizaciones anónimas que mantienen el statu quo imponiendo su fuerza injustificada e indiscriminadamente.

Por su parte, la hostilidad de la ciudad-sueño del escritor rumano se concreta en lugares que acogen actos de extrema violencia o que, por sus características, son aptos para ellos. Cabe destacar a este respecto las sillas de dentista dotadas de instrumental quirúrgico, empleadas para crueles vejaciones; el gran museo del dolor en cuyas vitrinas se exponen los huesos ilíacos de cientos de mujeres asesinadas; y, por encima de cualquier otro lugar, la gran sala circular antes mencionada, escenario de sacrificios y torturas que acaban con la vida de varias mujeres. 
En cambio, en otras ocasiones los espacios son adversos, no tanto por lo que se puede ver en ellos, sino, justamente, por lo que esconden. Regresar, internarse en ellos es el único modo en que el protagonista puede hallar algunas respuestas, encontrar aquello que le ha sido ocultado. Ello implica retroceder al pasado, un pasado que los escenarios de la infancia guardan celosamente. Por tanto, la ciudad onírica conduce a Mircea una y otra vez a la casa natal y a la de la primera niñez, con el objetivo de hacer aflorar los recuerdos y activar los procesos necesarios para comprender.

Una diferencia significativa que presenta la ciudad-sueño en la narrativa de Levrero y Cărtărescu es que en la primera los espacios privados y, en concreto, los destinados a la vivienda carecen siempre de los valores de protección y seguridad que por lo general se asocian a la casa (Bachelard 1975; Gullón 1980). Bien al contrario, los personajes levrerianos experimentan ante la casa un sentimiento de ajenidad, de desapego e, incluso, de repulsa similar al que les generan los demás escenarios urbanos. Ello es así incluso cuando, encerrado en un lugar desconocido (como le sucede al protagonista de El lugar), la casa es evocada desde la distancia como un refugio, que resultará a la postre, cuando por fin se llega a ella, hostil en igual o mayor medida, pues no ofrece la intimidad y privacidad esperadas. En otros textos del uruguayo, como Desplazamientos, el signo negativo de la vivienda alcanza también a la casa paterna, heredada, que contiene los recuerdos de la infancia y que, lejos de representar una excepción, se reafirma como un espacio enajenante, como "un territorio conflictivo que impone una despersonalización y un trastocamiento perturbador del yo" (Verani 1996: 47). Aquí, este lugar, donde el propietario no es más que un intruso entre sus verdaderos habitantes, resulta angustioso. Primero, porque suscita sentimientos contradictorios (rencor hacia el padre y, al mismo tiempo, dolor por su muerte) y, segundo, porque en su interior se suceden múltiples realidades, alternativas y excluyentes. En una de ellas, en concreto, el protagonista llega a cometer actos brutales, como la violación de una de las inquilinas. 
En cambio, en el caso del autor rumano, la casa, percibida ahora sí como hogar, es un lugar recurrente en el modelo de la ciudad-sueño, que sufre también las alteraciones propias de esta, pero sin perder los valores positivos que connota. Bien al contrario, las viviendas del pasado, donde han transcurrido la adolescencia y, especialmente, la infancia del protagonista, son idealizadas. Los recorridos de Mircea por ese continuum realidad-alucinación-sueño antes mencionado lo llevan de nuevo a estos espacios del pasado que conservan intacto el universo de la niñez: volver a esos escenarios significa entonces retroceder en el tiempo, por completo espacializado. Aun cuando algunos espacios circundantes (el patio, las escaleras, los sótanos del bloque o el subsuelo de la villa) pueden presentar carácter hostil, el espacio interior, familiar, por excelencia materno, es el refugio en el que el joven puede sentirse a salvo.

Otro rasgo común a ambos escritores en lo que a la creación del modelo de la ciudad-sueño respecta es la libre recreación de la materia histórica. Tanto Levrero como Cărtărescu toman como base circunstancias efectivas de la ciudad real, extraliteraria, que les sirve de referente. Al ser ficcionalizadas, estas estarán, como en general cualquier elemento espacial independientemente de su origen, sujetas a las alteraciones características del modelo. En París conviven a un mismo tiempo Carlos Gardel - a quien el protagonista sabe "irreversiblemente muerto" (Levrero [1980] 2010: 109) y a quien sin embargo presencia cantando en el Odeón' - y las tropas hitlerianas, que, en el contexto de una guerra transmitida televisivamente, se hallan a punto de entrar en la capital francesa, tras haber invadido Polonia, mientras miembros activos de la Resistencia se organizan para tratar de impedir la invasión.

Orbitor, concretamente el tercer tomo, recrea la Revolución rumana de diciembre de 1989 con una particular mezcla entre realidad y ficción. En este episodio, el modelo de la ciudad-sueño

\footnotetext{
9 Jorge Olivera (2011) describe este fenómeno - es decir, el clima de extrañamiento que se genera cuando el protagonista, que tenía la certeza de la muerte de Gardel, lo ve vivo, o cuando cree estar viviendo a fines de los sesenta y ve en la televisión la invasión nazi de Francia- en términos de ucronía.
} 
alcanza su punto culminante, puesto que no se adscribe ya a la alucinación o reverie de un determinado personaje, sino que abarca a la totalidad de la población bucarestina. La propuesta ficcional de Cărtărescu es en realidad una alegoría que, pese al onirismo que planea por todo el episodio, se construye sobre personajes y acontecimientos de la realidad extraliteraria, consignados o no por el relato oficial de los hechos. Es en el planteamiento final, con la destrucción completa de la ciudad por acción divina, cuando verdaderamente se distancia de aquella. En la reescritura del proceso revolucionario, las estatuas, que otrora se entregaban a los placeres sexuales, van a desempeñar un papel protagonista. Por una parte, la Revolución Rumana, una gigante mujer de piedra vestida con traje nacional ${ }^{10}$ que encarna los ideales democráticos de su pueblo, ayuda a los manifestantes protegiéndolos de los disparos con su propio cuerpo y alzándolos hasta el balcón de la sede del Comité Central del Partido Comunista Rumano, "centro supremo del poder" (Cărtărescu 2007: 418). La estatua, como la propia revolución que simboliza, resulta ser un artificio de un grupo de opositores y disidentes del régimen que conspiran para derrocar a los Ceaușescu y tomar el relevo, una vez que la pareja presidencial huye de la azotea del mentado edificio en helicóptero y es capturada, sometida a un juicio sumario y fusilada. En la reescritura de Cărtărescu, que retoma las teorías e incógnitas surgidas en torno a los sucesos de diciembre (Stefanescu 2004; Chavero Pozo 2001), la revolución aparentemente popular y espontánea escondería un auténtico golpe de Estado minuciosamente organizado desde ciertos sectores del régimen. La violación de esta estatua, perpetrada por los supuestos revolucionarios — con apodos que encubren apenas los nombres de personalidades reales-, representa la traición al movimiento popular y a sus reivindicaciones democráticas. La nueva fuerza

10 Esta estatua de diez metros de altura y pechos desnudos, ataviada con una cadena de ducados austríacos, falda de seda, saya y cintas con los tres colores de la bandera rumana en el pelo, ha sido diseñada por los conspiradores a imitación del cuadro de Constantin Daniel Rosenthal România revoluționară ("Rumanía revolucionaria”), "el emblema más conocido y más venerado de nuestro pueblo” (Cărtărescu 2007: 417). 
"revolucionaria", creada en la clandestinidad, recibe el nombre de Frontul Supraviețurii Noastre ("Frente de Nuestra Supervivencia”), cuyas siglas evocan, acentuando con el posesivo los intereses individuales de sus líderes, las de Frontul Salvării Naționale ("el Frente de Salvación Nacional”), que tomó, en la realidad extraliteraria, el gobierno del país tras las revueltas de diciembre.

Por otra parte, las esculturas de grandes personalidades de la política, la cultura o la historia rumanas que decoran los parques, los edificios y las plazas de Bucarest deciden abandonar su estatismo y habitual apariencia, lideradas por la enorme estatua de Lenin que presidía Casa Scânteii, ${ }^{11}$ para intervenir en el proceso revolucionario, formar un ejército y hacerse así con el poder. A través de la animación interesada de estas estatuas, podría ironizar Cărtărescu acerca de la "vieja guardia”, ex mandatarios o cargos medios del partido único que, no queriendo permanecer ajenos a los acontecimientos que sacuden al país, se suman a la causa revolucionaria con el claro objeto de beneficiarse en la nueva coyuntura.

Si Levrero emplea deliberadamente las referencias a personajes y hechos reales para acentuar la confusión a que se enfrenta el personaje, como el lector, en el entorno urbano, acrecentando la imposibilidad de comprenderlo desde una óptica estrictamente racional, Cărtărescu lleva al extremo ese continuum planteado a lo largo de toda la trilogía y cuestiona asimismo el relato oficial, u oficialista, de unos hechos recientes de vital importancia en su país, sobre los que hay todavía muchos aspectos por aclarar.

A través de este modelo, el autor uruguayo pone en tela de juicio la concepción misma de realidad, la percepción racionalista del mundo. Por tanto, Mario Levrero sitúa el foco en la interioridad del individuo, en la manera en que se perciben y conceptualizan los fenómenos que les sobrevienen a los personajes, fenómenos plurales y complejos que no pueden ser abarcados o interpretados

11 Este edificio, sede del periódico oficialista Scânteia ("La Chispa”), es uno de los grandes hitos de la ciudad comunista. Construido en la década de 1950, durante el mandato de Gheorghiu-Dej, Casa Scânteii es muestra de una influencia soviética que sobrepasa el plano de la arquitectura y que se extendió a otros muchos ámbitos tras 1947. 
desde criterios rigurosos, exhaustivos. Algunas de las características de la narrativa levreriana mencionadas han generado controversia y debates críticos. Frente a los estudiosos que abordan sus novelas desde lo fantástico, el surrealismo o, incluso, la ciencia ficción, otros prefieren los términos de subjetivismo o, como Rocca (Citado en Echevarría 2010: 9), de realismo introspectivo o interior, en la línea del propio autor. Levrero defendía el realismo de sus textos, reivindicando de esta manera una noción más extensa de la realidad, más inclusiva, que dé cabida a las experiencias oníricas y, en general, a cualquier manifestación del mundo interior. En una entrevista con Pablo Rocca, en 1992, afirmaba:

la crítica literaria parece dar por sentadas muchas cosas, entre ellas la existencia de un mundo exterior objetivo, y a partir de ahí señala límites precisos a la realidad y al realismo, da por sentado que el mundo interior es irreal o fantástico y trata de rotularlo todo de acuerdo con estos puntos de partida arbitrarios y pretenciosos (Levrero 1992: 1168).

Para Levrero, "la literatura es una de las formas posibles de comunicar a otros seres una experiencia personal que cae fuera de las formas habituales de percepción" (Levrero 1992: 1168). Esta concepción individualista, subjetiva o subjetivada (García 2015) de la literatura se aleja de la certidumbre de los paradigmas culturales, así como, de acuerdo con Rivadeneira (2014: 109), del realismo hegemónico, a través de la adopción de "una estética rara que recurre a lo onírico y la fantasía como forma de cuestionar y superar la realidad existente".

En cambio, Mircea Cărtărescu, aunque aborda también esta problemática de la convivencia, muchas veces indiferenciada, de los distintos estados (vigilia, sueños, realidad, imaginación, recuerdo...), traslada el acento sobre los mecanismos de la ficción literaria. La ciudad-sueño en Cărtărescu es construida y deconstruida en un mismo texto literario, puesto que se pone de relieve el carácter ficcional de este y de cualquier otro modelo urbano presente en ella. El juego metatextual involucra a todos los personajes — conscientes de su condición de criaturas de papel- 
y también a la ciudad de Bucarest. Construida en las tres novelas con minuciosidad, respetando en gran medida el referente espacial que toma como base (la mayoría de las calles, las plazas, los barrios e incluso los edificios o estatuas en que se ambienta la trilogía es rastreable en el mapa bucarestino, en virtud de sus nombres y de sus características físicas, que generalmente se conservan) y adquiriendo a un tiempo multiplicidad de sentidos, la capital deviene falaz, un mero decorado creado ad hoc, para albergar hechos y actantes que, con independencia de que se puedan hallar o no correlatos extraliterarios, son ante todo, tal como explicita el artífice del manuscrito de Orbitor, ficcionales.

A modo de conclusión, se puede señalar que la aproximación comparada a la obra de Mircea Cărtărescu y Mario Levrero que se ha realizado a lo largo del presente trabajo evidencia una similitud en la configuración de determinados espacios narrativos. Dicha configuración, que responde a la metáfora urbana de la ciudadsueño - tal como ha sido expuesta y definida en la primera parte del estudio-, está en estrecha relación con el onirismo, un elemento determinante en la narrativa de ambos autores. El componente onírico, así como la porosidad o continua interconexión entre el mundo del sueño y el mundo de la vigilia, se manifiestan, además de en ciertos aspectos de la trama e incluso de la caracterización de los personajes, en la construcción del espacio literario. Lejos de ser un mero marco o decorado para la acción narrativa, las urbes y demás espacios ficcionales tienen, en las obras analizadas y, en general, en buena parte de la producción de los dos escritores, una función de primer orden. Estos lugares cambiantes, por lo común hostiles, incomprensibles para quienes los habitan o recorren, condicionan la conducta de los personajes - y adquieren, por tanto, gran importancia en el desarrollo de los hechos-, al tiempo que se erigen un elemento central de la poética de ambos autores.

Es justamente en este aspecto, la función que desempeña el modelo de la ciudad-sueño en la concepción literaria de cada autor, donde radica la principal diferencia entre ellos. De acuerdo con la idea que de la literatura tiene Levrero a la que se ha hecho alusión 
anteriormente, la metáfora de la ciudad-sueño constituiría en sus textos un mecanismo más a través del que comunicar esas otras realidades, de naturaleza por lo común subjetiva, que cuestionan el paradigma de lo racional, la visión imperante, reduccionista y excluyente, acerca de qué es la realidad. Para el escritor rumano, en cambio, esta metáfora participa de un juego metaliterario en el que la urbe, como todo el texto en el que esta se construye, resulta abiertamente ficticio por cuanto se alude de manera directa a su naturaleza discursiva. En la trilogía, al igual que en otras obras, se explicitan los procesos de construcción del espacio literario, en tanto que parte de los mecanismos de la escritura. Por tanto, se podría aplicar a la ciudad-sueño, como al resto de modelos presentes en su narrativa, aquello que McHale (1996) afirma a propósito de las heterotopías: el espacio no es tanto construido como deconstruido por el texto o, mejor dicho, construido o deconstruido al mismo tiempo.

\section{Referencias bibliográficas}

AxINTE, Șerban

2007 "Lumea intr-un singur cuvânt: Orbitor". Observator cultural. 131. Consultado: 27 de abril de 2016. <http://www.romaniaculturala.ro/articol.php?cod $=4947>$.

Centrul de Cercetare al Imaginarului

2005 "Mircea Cărtărescu despre holarhie, metaforă, fractali. O introspectie". Dezbaterile Phantasma. Consultado: 25 de abril de 2018. <http://phantasma.lett.ubbcluj.ro/?p=3360>.

BACHELARD, Gaston

1975 La poética del espacio. México D.F.: Fondo de Cultura Económica.

BÂRLEANU, Călin-Horia

2011 Mircea Cărtărescu. Universul motivelor obsedante. Iaşi: Editura Universitas XXI.

Bello Rodríguez, Carlos

2014 Mario Levrero tocando la orilla: el caso de Nick Carter y Caza de conejos". Andex. Revista de estudios literarios y culturales. $1,84-100$. 
CĂRTĂREscu, Mircea

2007 Orbitor. Aripa dreaptă. Bucureşti: Humanitas.

[2002] 2008 Orbitor. Corpul. Bucureşti: Humanitas.

[1996] 2014 Orbitor. Aripa stângă. Bucureşti: Humanitas. Edición digital.

[1992] 2011 Eminescu: Visul chimeric. Bucureşti: Humanitas.

Chavero Pozo, José Javier

2001 “La Revolución rumana de 1989”. Papeles del Este. Transiciones poscomunistas. 2, 3-18.

Chevalier, Jean

[1969] 1986 Diccionario de los símbolos. Trad., Manuel Silvar y Arturo Rodríguez. Barcelona: Herder.

ChițAn, Simona

2007 “Golgota lui Cărtărescu. Interviu cu Mircea Cărtărescu”. Evenimentul zilei. 4857. Consultado: 26 de abril de 2016. <http:// www.romaniaculturala.ro/articol.php?cod=3953>.

Ciobanu, Vitalie

2002 "Lupta lui Mircea cu Îngerul”. Contrafort. 1-3, 87-89. Consultado: 26 de abril de 2016. <http://www.contrafort.md/ old/2002/87-89/272.html>.

Corbellini, Helena

1996 "Mario Levrero: las tradiciones del soñante". Nuevo texto crítico. III. 16/17, 19-34.

CoşoveI, Ştefania

2009 "Visul e o parte a realității. Interviu cu Mircea Cărtărescu”. Luceafărul de dimineață. 9. Consultado: 20 de mayo de $\quad 2017 . \quad<$ http://www.revistaluceafarul.ro/index. html id=1011\&amp;editie $=51>$.

De Rosso, Ezequiel

2013 La máquina de pensar en Mario. Ensayos sobre la obra de Levrero. Buenos Aires: Editora Eterna Cadencia.

ECHEVARRía, Ignacio

2008 "Posfacio. Levrero y los pájaros". En Conversaciones con Mario Levrero. Ed., Pablo Silva Olazábal. Montevideo: Ediciones Trilce, 93-102.

2010 “Prólogo" en Levrero [1970] 2010: 7-13. 
Eguía Armenteros, Diana

2017 "El texto en borrador de Mario Levrero (La novela luminosa y El discurso vacio)”. Bulletin of Hispanic Studies. XCIV, 3, 337-350.

EvseEv, Ivan

1994 Dicționar de simboluri și arbetipuri culturale. Timișoara: Amarcord.

GARCíA, Mariano

2015 "Las dos caras de la autoficción en La novela luminosa de Mario Levrero". Pasavento. Revista de Estudios Hispánicos. III, 1, 137-153.

Gullón, Ricardo

1980 Espacio y novela. Barcelona: Antoni Bosch.

LeVrero, Mario

[1970] 2010 La ciudad. Barcelona: DeBolsillo.

[1980] 2010 París. Barcelona: DeBolsillo.

[1982] 2010 El lugar. Barcelona: DeBolsillo.

1992 "Entrevista imaginaria con Mario Levrero". Revista Iberoamericana. LVIII, 160-161, 1167-1177.

MARTínez, Luciana

2017 "Correspondencia y Symphilosophie. Consideraciones sobre el intercambio epistolar de Mario Levrero y Francisco Gandolfo". Confluenze. Rivista di Studi Iberoamericani. IX, 2, 248-257.

Martínez SÁnchez, Rocío

2016 "Posturas del narrador en los diarios ficcionales de Mario Levrero”. Tonos digital. Revista de Estudios Filológicos. 31. Consultado: 20 de mayo de 2017. <http://www.um.es/tonosdigital/znum31/perfiles.htm>.

McHale, Brian

1996 Postmodernism fiction. London: Routledge.

MonTOYa JuÁrez, Jesús

2013 Mario Levrero para armar. Jorge Varlotta y el libertinaje imaginativo. Montevideo: Trilce. 
Oliver, María Paz

2013 "El arte de irse por las ramas: la digresión en La novela luminosa de Mario Levrero". Revista Hispánica Moderna. LXVI, 2, 205-219.

Olivera, Jorge

2008 "Intrusismos de lo real en la narrativa de Mario Levrero". Tesis doctoral. Universidad Complutense de Madrid.

2011 "Dos versiones del exilio en París: Mario Levrero y Carlos Gardel”. Revista de Filología Románica, Anejo VII, 331-338. https://doi.org/10.5209/rev_rfrm.2011.38707

Pereira, Luis

2013 "Yo no he escrito nada que no haya vivido. Entrevista a Mario Levrero". En Un silencio menos. Conversaciones con Mario Levrero. Comp., Elvio Gandolfo. Buenos Aires: Mansalva, 70-72.

Pérez Armendáriz, David

2017 "Mario Levrero y la novela policial”. Quimera: Revista de literatura. $402,30-32$.

Pop, Delia

2010 Provocări ale postmodernitătii. Pornind de la Mircea Cărtărescu. Iaşi: Princeps Edit. Rivadeneira, Blas Gabriel

2014 "La Ciudad como imposible y farsa. Una lectura crítica de Mario Levrero". El taco en la brea. 1, 108-121.

Stefanescu, Barbu

2004 "La transición de la dictadura a la democracia. El caso de Rumanía”. Pasado y memoria. Revista de historia contemporánea. 3, 5-28. https://doi.org/10.14198/pasado2004.3.12

Teodorescu, Cristian

2007 "Coşmarul meu a fost că nu-mi voi putea termina trilogía". Cotidianul. 2. Consultado: 26 de abril de 2016. <http://www. romaniaculturala.ro/articol.php?cod=3951>.

Tuca, Marius, y Mihaela Suciu

2005 "Eu-rile lui Mircea Cărtărescu". Jurnalul Național (15/06/2005). Consultado: 3 de mayo de 2018. <http:// jurnalul.ro/special-jurnalul/interviuri/eu-rile-lui-mircea-cartarescu-42955.html> 
Ungureanu, Delia

2007 "Visul robitor al Orbitorului". Observator cultural. 131. Consultado: 27 de abril de 2016. <http://www.romaniaculturala. ro/articol.php? cod=4947>.

VeCCHIO, Diego (dir.)

2016 Cuadernos LIRICO. 14 "Levrero" (número dedicado íntegramente a Mario Levrero).

Verani, Hugo Juan

1996 “Mario Levrero: aperturas sobre el extrañamiento”. Nuevo texto crítico. III. 16/17, 45-58.

Recepción: 19/05/2018

Aceptación: 19/11/2019 